DOI https://doi.org/10.30525/978-9934-26-074-2-77

\title{
СТРАТЕГІЧНЕ СПІВРОБІТНИЦТВО УКРАЇНИ 3 ЄВРОПЕЙСЬКИМ ПОЛІЕЙСЬКИМ ОФІСОМ У ГАЛУЗІ ПРОТИДІЇ ТРАНСНАЦІОНАЛЬНОЇ ОРГАНІЗОВАНОЇ ЗЛОЧИННОСТІ
}

\author{
Казік Т. В. \\ аспірантка другого року навчання \\ за науковою спеиіальністю «081-Право» \\ ВН3 «Університет економіки та права «КРОК» \\ м. Київ, Украӥна
}

На сучасному етапі поглиблення інтеграційних процесів у різних сферах життя, вирішення питання протидії та боротьби з організованою злочинністю, що набуває нових форм із застосуванням складних механізмів реалізації, набуває все більш важливого значення для кожного суб'єкта міжнародних відносин.

Загальновідомо, що між країнами-учасницями Свропейського Союзу (далі - ЄС) фактично поняття «внутрішнього кордону» перестає існувати, тому як громадянин країни, що входить до ЄС має можливість до вільного пересування без проходження прикордонного контролю 3 іншою державою-членом СС. А отже, для майже всіх європейських країн організована злочинність немає конкретної території дії та стає загрозою для будь-якої держави.

В цьому аспекті для країн-учасниць $С С$ актуально вести протидію та боротьбу на глобальному - транснаціональному рівні, не тільки в межах інтеграційного об'єднання, а й зосереджувати увагу на співпраці 3 іншими державами. Саме для вирішення вищезазначених питань було створено Європейський поліцейський офіс (далі - Європол). Так, підтвердженням такої думки є праця І. К. Гришко [1], в якій автор визначає, що злочинність сьогодення набуває нових форм та виходить за межі кордонів конкретної держави, що і надає їй транснаціонального характеру.

В. С. Полянська [2] наголошує на активізації глобальної загрози через відкриття економічних ринків, яка в сукупності негативно впливає на соціальний, економічний, політичний та, навіть, культурний розвиток держави. Правовому аспекту регулювання міжнародного співробітництва нашої країни з Європолом задля подолання злочинності 
особливу увагу приділяють М. М. Сірант [3], I. I. Маринів та П. С. Мохончук [4].

Стратегічне співробітництво Європолу з Україною було започатковане у 2004 році шляхом організації двостороннього діалогу відповідно до поставленої задачі Радою Європейського Союзу. Так, договірноправова база включає наступні міжнародні документи: 1) Угода між Україною та Свропейським поліцейським офісом про стратегічне співробітництво [5], що почала діяти з 16.11 .2010 року та втратила чинність на підставі прийняття правонаступного акту; 2) Угода між Україною та Свропейським поліцейським офісом про оперативне та стратегічне співробітництво [6], що ратифіковано 12.07.2017 року.

Відповідно до Статті 1 кожного із актів, де визначається мета угоди, варто зауважити те, що Угода від 2010 року закріплювала саме посилення взаємодії України та держав-членів СС, де Європол виступає як діюче агентство, через яке виконується співпраця, тоді як в Угоді від 2017 року Європол виступає вже як самостійний незалежний підрозділ, що представляє інтереси держав-учасниць СС.

Так, розглядаючи, вищевказану обставину, доцільно зауважити, що вона виникає через проблеми правосуб'єктності Європолу та подальшу еволюцію міжнародно-правового статусу даного відомства. Адже, починаючи 3 травня 2017 року, Свропейський парламент розширює повноваження Сврополу для функціонування як окремого підрозділу ЄC у якості юридичної особи для оперативного реагування, тому як попередній статус вимагав постійного ратифікаційного процесу державами-членами СС. У зв'язку з цим, співробітництво України 3 Європолом з 2017 року набуває нового формату тісної взаємодії з розширеними можливостями кожної сторін у правому аспекті.

Доцільно відмітити появу нового розділу, а саме «Визначення», де надається трактування «інформації», що підлягає обміну, як персональні та неперсональні дані. А отже, дане визначення $\epsilon$ повністю антонімічним порівняно з Угодою від 2010 року, де в пункті 2 Статті 1 зазначається, що договір не надає уповноваженим органам кожної із сторін функцій «на передачу даних, які стосуються встановленої особи чи особи, яку може бути встановлено» [5]. Порівняно з першим документом, у преамбулі другого [6] вже просліджується вживання проблеми організованої злочинності з транснаціональним характером. Таким чином, просліджується розширення компетенцій для більш ефектної співпраці та результативності у розслідуванні справ.

Отже, розглянемо результати співробітництва більш предметно. Серед останніх резонансних справ транснаціонального характеру в галузі протидії організованої злочинності, що було викрито у співробітництві 
України з міжнародними партнерами, включаючи Свропол, слід згадати міжнародну спецоперацію «ЕМОТЕТ» (січень 2021 рік) [7] та міжнародну шахрайську схему злочинного заволодіння коштами фізичних осіб (грудень 2020 рік) [8]. У кожній операції Свропол відігравав роль координаційного центру [9] та працював в рамках спеціальної 4-х річної програми (оригінальна назва - EU Policy Cycle) щодо боротьби с найбільш актуальними злочинними, загрозами Європейського Союзу - ЕМРАСТ.

За масштабами ці дві справи насправді досить різні, однак просліджується одна важлива риса - серед організаторів встановлено причетність громадян України. Як наслідок, для блокування злочинних дій міжнародна кооперація базувалася на розслідуваннях, що провели відповідальні органи 3 української сторони. У першій справі було залучено Департамент кіберполіції, Головне слідче управління та Генеральну прокуратуру України. Для викриття другої справи Департамент стратегічних розслідувань Національної поліції України.

Аналізуючи зведені показники за двома справами слід зазначити, що негативні наслідки та збитки від діяльності злочинного угрупування у першій справі є більш серйозними, тому як хакери почали атаку ще 3 2014 року та мали стійку та розгалужену систему, що включала більше як 90 серверів у різних куточках світу. Як висновок, злочинна організація може бути викрита через місяць або рік, а деякі злочини 3 транснаціональним характером займають аж до 7-8 років. Так, найбільшої загрози, в період інформаційної епохи, представляють саме кіберзлочини, для яких не існує кордонів та меж. Саме тому, дуже важливо спільними зусиллями не тільки на міждержавному рівні, а й на рівні міжнародних організацій об'єднуватися для подолання найбільш болючого питання - протидії організованої злочинності.

\section{Література:}

1. Гришко I. К. Питання боротьби зі злочинністю в праві Європейського Союзу. Iнституйійний репозитарій eNULAUIR Національного юридичного університету імені Ярослава Мудрого. URL: https://dspace.nlu.edu.ua/bitstream/123456789/15145/1/Grushko.pdf (дата звернення: 10.04.2021).

2. Полянська В. С. Питання європейського співробітництва в протидії транснаціональній організованій економічній злочинності. Науковий вісник Начіональної академії внутрішніх справ. 2018. № 3 (108). C. 67-79. URL: http://elar.naiau.kiev.ua/bitstream/123456789/ 13484/1/8.pdf (дата звернення: 10.04.2021). 
3. Сірант M. М. Поліцейське співробітництво України i Європейського Союзу - правовий аспект. Національний університет «Львівська політехніка». Наукові журнали та конферениії. URL: http://science.lpnu.ua/sites/default/files/journal-paper/2017/aug/5753/ vnulpurn201685054.pdf (дата звернення: 10.04.2021).

4. Маринів I. І., Мохончук П. С. Роль агенції Свропейського Союзу з правоохоронного співробітництва в боротьбі 3 міжнародною організованою злочинністю. Науковий вісник Ужгородського наиіонального університету. 2019. Випуск 55. Том 2. С. 157-159. URL: https:// dspace.nlu.edu.ua/bitstream/123456789/16398/1/Maruniv_Mohonchuk_157159.pdf (дата звернення: 10.04.2021).

5. Угода між Україною та Європейським поліцейським офісом про стратегічне співробітництво. Верховна Рада Украӥни. Законодавство України. URL: https://zakon.rada.gov.ua/laws/show/994_954\#Text (дата звернення: 10.04.2021).

6. Угода між Україною та Європейським поліцейським офісом про оперативне та стратегічне співробітництво. Верховна Рада України. Законодавство Украӥни. URL: https://zakon.rada.gov.ua/laws/show/ 984_001-16\#Text (дата звернення: 10.04.2021).

7. Кіберполіція викрила транснаціональне угруповання хакерів у розповсюдженні найнебезпечнішого в світі комп'ютерного вірусу «ЕМОТЕТ». Офіційний сайт Наиіональної поліиії. URL: https://www.npu.gov.ua/news/kiberzlochini/kiberpolicziya-vikrilatransnaczionalne-ugrupovannya-xakeriv-u-rozpovsyudzhenni-najnebezpechnishogo-v-sviti-komp-yuternogo-virusu-EMOTET/ (дата звернення: 10.04.2021).

8. Нацполіція спільно з Офісом Генпрокурора та німецькими колегами викрили міжнародну шахрайську «схему» 3 місячним оборотом у 10 мільйонів євро. Офіційний сайт Національної поліиії. URL: https://www.npu.gov.ua/news/majnovi-zlochini/naczpolicziya-spilno-zofisom-genprokurora-ta-nimeczkimi-kolegami-vikrili-mizhnarodnushaxrajsku-sxemu-z-misyachnim-oborotom-u-10-miljoniv-jevro/ (дата звернення: 10.04.2021).

9. World's most dangerous malware emotet disrupted through global action. Europol. URL: https://www.europol.europa.eu/newsroom/news/ world $\%$ E2\%80\%99s-most-dangerous-malware-emotet-disrupted-throughglobal-action (дата звернення: 10.04.2021). 